\title{
Salmonella overcomes tumor immune tolerance by inhibition of tumor indoleamine 2, 3-dioxygenase 1 expression
}

\author{
Yu-Diao Kuan ${ }^{1}$, Che-Hsin Lee ${ }^{1,2}$ \\ ${ }^{1}$ Graduate Institute of Basic Medical Science, School of Medicine, China Medical University, Taichung, Taiwan \\ ${ }^{2}$ Department of Microbiology, School of Medicine, China Medical University, Taichung, Taiwan \\ Correspondence to: Che-Hsin Lee, e-mail: chlee@mail.cmu.edu.tw
}

Keywords: salmonella, tumor-targeting, indoleamine 2, 3-dioxygenase 1, immune tolerance

Received: May 31, 2015

Accepted: October 22, 2015

Published: October 28, 2015

\section{ABSTRACT}

Over the past decades, Salmonella has been proven capable of inhibiting tumor growth. It can specifically target tumors and due to its facultative anaerobic property, can be more penetrative than other drug therapies. However, the molecular mechanism by which Salmonella inhibits tumor growth is still incompletely known. The antitumor therapeutic effect mediated by Salmonella is associated with an inflammatory immune response at the tumor site and a $\mathrm{T}$ cell-dependent immune response. Many tumors have been proven to have a high expression of indoleamine 2, 3-dioxygenase 1 (IDO), which is a rate-limiting enzyme that catalyzes tryptophan to kynurenine, thus causing immune tolerance within the tumor microenvironment. With decreased expression of IDO, increased immune response can be observed, which might be helpful when developing cancer immunotherapy. The expression of IDO was decreased after tumor cells were infected with Salmonella. In addition, Western blot analysis showed that the expression levels of phospho-protein kinase B (P-AKT), phospho-mammalian targets of rapamycin (P-mTOR), and phospho-p70 ribosomal s6 kinase (P-p70s6K) in tumor cells were decreased after Salmonella infection. In conclusion, our results indicate that Salmonella inhibits IDO expression and plays a crucial role in anti-tumor therapy, which might be a promising strategy combined with other cancer treatments.

\section{INTRODUCTION}

Bacterial cancer therapy can be traced back to the 19th century: a sarcoma surgeon found that bacterial infection has a beneficial influence on patients with tumors [1]. Since then, researchers have been developed many cancer therapies based on the use of bacteria, attenuated bacteria strains or bacterial products such as Streptococcus and Serratia species [2,3], Clostridia species [4], and Mycobacterium bovis-made Bacillus Calmette-Guerin, commonly used in bladder cancer [5]. Salmonella is one bacterium that has been known for years to have proven antitumor efficacy. This species has several advantages that apply to cancer therapy: because it is flagellated, Salmonella can penetrate deeply into tumor tissue yet viruses, drugs and antibodies cannot [6] and because it is a facultative anaerobe, Salmonella can colonize small metastatic and larger tumors [7]. Additionally, Salmonella was found to replicate much more in tumors than in normal tissue. $[8,9]$.

Until now, one of the barriers to curing cancer has been tumor immune tolerance, which renders host immunity unable effectively to recognize or kill tumor cells; in some situations, immune cells even undergo inactivation cell cycle arrest and apoptosis $[10,11]$. Some factors have been reported that give tumor cells the ability to escape from host immunity, including interferon- $\gamma$ (IFN- $\gamma$ ) [12], galectin [13], transforming growth factor $\beta$ (TGF- $\beta$ ) [14], and indoleamine 2, 3-dioxygenase 1 (IDO1) [15]. In particular, IDO increase the concentration of kynurenine, leading to activation of regulatory $\mathrm{T}$ cells, inactivation of effective $\mathrm{T}$ cells and even apoptosis of immune cells [16]. There are some treatments that focus on overcoming this obstacle. 1-methyl tryptophan (1-MT) is an analog of IDO substrate that has a higher affinity and is usually used in combination with chemotherapeutic drugs 
[17]. 1-MT exist two isoforms, 1-methyl-D-tryptophan (D-1-MT) and 1-methyl-L-tryptophan (L-1-MT). L-1-MT is considered as a more potent IDO inhibitor, while D-1-MT was commonly chosen for clinical trial with more effective antitumor activity and superior ability of abrogating immune inhibition [18]. However, there are still some concerns about administering 1-MT [19].

Previous studies have demonstrated that Salmonella can decrease angiogenesis and increase infiltration of immune cells within a tumor region, ultimately leading to inhibition of tumor growth [20]. Some studies indicate that Salmonella activates the $\mathrm{CD}^{+} \mathrm{T}$ cell immune response to eliminate tumor cells [21]. This phenomenon can be verified in a T cell-deficient mouse, in which Salmonellamediated tumor regression was inhibited, as was the infiltration of neutrophils and macrophages in the tumor region [22]. These findings suggest that Salmonella might mainly activate $\mathrm{CD}^{+} \mathrm{T}$ cell immunity within a tumor region. Thus, we postulate that the underlying mechanism is that Salmonella can break IDO-mediated immune tolerance in the tumor microenvironment.

Autophagy is a term first coined by Christian de Duve and describes a process in which cells degrade misfolded or aggregated protein or even organelles to recycle the components to help the cell overcome stress [23]. Some cancer cells are believed to have a reduced autophagic property, thereby promoting oncogenesis [24]. Moreover, our and other studies indicate that Salmonella can induce autophagy of immune cells and tumor cells through phospho-protein kinase B (P-AKT)/phosphomammalian targets of the rapamycin (P-mTOR) pathway [25]. The regulation of autophagy can also affected by the upstream factor controlling IDO expression, which infers that autophagy might be related to the immune response [26]. These findings connect the relationships between Salmonella, cancer and host immunity, while the detailed molecular mechanism still needs further investigation. As a result, we postulate that Salmonella-induced autophagy is involved in the process of Salmonella regulating IDO to hinder tumor immune tolerance. We hope these findings can lead to a potential treatment that evokes host immunity to conquer cancer.

\section{RESULTS}

\section{Salmonella downregulated kynurenine and enhanced the viability of $T$ cells}

It has been suggested that kynurenine has the ability to increase T cell apoptosis [27]. As shown in Figure 1A and 1B, Salmonella can decrease the production of kynurenine in a dose-dependent manner in B16F10 and 4T1 cells. Kynurenine decreased significantly when cells were treated with highest dose of Salmonella (multiplicity of infection $(\mathrm{MOI})=100)$. Thus, we analyze whether Salmonella-mediated decrease of kynurenine in B16F10 and 4T1 has impact on T cell survival. The culture medium of cells which have been treated with Salmonella was used to incubate Jurkat cells (T cells) to measure T cell viability. The results show that the amounts of $\mathrm{T}$ cells are highest when T cells were cultured in medium of cells treated with highest dose of Salmonella compared with control group (Figure 1C and 1D). These results suggest that Salmonella can increase the survival rate of T cells through inhibiting kynurenine produced by tumor cells.

\section{Salmonella regulated IDO expression through phospho-protein kinase B (P-AKT)/phospho- mammalian targets of the rapamycin (P-mTOR) pathway}

We demonstrated that Salmonella can decrease the production of kynurenine and reverse kynureninemediated $\mathrm{T}$ cell death. As a result, the enzyme responsible for kynurenine production, IDO, should be inhibited by Salmonella. B16F10 cells and 4T1 cells were treated with various degrees of infection (MOI) of Salmonella to investigate the ability of Salmonella to IDO through induction of AKT/mTOR pathway. The AKT/mTOR/ p70 ribosomal s6 kinase (p70S6K) signaling pathway negatively regulates autophagy. We next examined the $\mathrm{AKT} / \mathrm{mTOR} / \mathrm{p} 70 \mathrm{~S} 6 \mathrm{~K}$ signaling pathway after Salmonella infection. In a dose-dependent manner, treatment with Salmonella decreased the phosphorylation of AKT, mTOR and p70S6K, indicating inhibition of the AKT/ $\mathrm{mTOR} / \mathrm{p} 70 \mathrm{~S} 6 \mathrm{~K}$ pathway by Salmonella in B16F10 cells (Figure 2A). Furthermore, very similar results were observed when Salmonella was used to treat 4T1 cells (Figure 2B). The results demonstrated that Salmonella can significantly decrease the expression of IDO and AKT/mTOR signaling both in B16F10 and 4T1 cells. To confirm whether AKT/mTOR signaling pathway truly participates in a Salmonella-induced decrease of IDO, cells were treated with autophagy inhibitor (an inhibitor of phosphatidylinositol 3-kinases (PI3K)), 3-Methyladenine (3-MA). 3-MA could restore Salmonellainduced downregulation of IDO (Figure 3A and 3B). Determination of the kynurenine expression assay showed that treatment of tumor cells with 3-MA resulted in inhibition of Salmonella-reduced kynurenine expression. The production of kynurenine could also be reversed after 3-MA treatment (Figure 3C and 3D). However, adding 3-MA alone had little or even no effect on the expression of IDO and kynurenine, indicating that the autophagy signaling pathway might play the role in the Salmonellamediated decrease of IDO and related catabolic products.

\section{Salmonella reduced the expression of IDO via inhibition of the AKT signaling pathway}

The constitutively active AKT was used to confirm our findings. We found that Salmonella inhibited the expression 
of IDO by reducing AKT phosphorylation. The AKT/mTOR/ p70S6K signaling pathway was reversed by transfecting constitutively active AKT plasmid. The suppressive effect of Salmonella on the AKT/mTOR/p70S6K signaling pathway was relieved by transfecting constitutively active AKT plasmid in B16F10 (Figure 4A) and 4T1 (Figure 4B) cells. By blocking the cascade of autophagy, the expression of IDO in B16F10 cells treated with Salmonella and constitutively AKT also reversed, implying that mTOR/AKT participates in the Salmonella-regulated decrease of IDO. Transfection of constitutively active AKT plasmid reduced the conversion of LC3-I to LC3-II by Salmonella treatment in comparison with vector only control transfection. The Salmonella-reduced expression of IDO was also reduced after Salmonella treatment by transfecting constitutively active AKT plasmid (Figure 4A and 4B). Our results suggest that inhibition of $\mathrm{P}-\mathrm{AKT}$ is required for Salmonella-reduced expression of IDO in tumor cells.

A
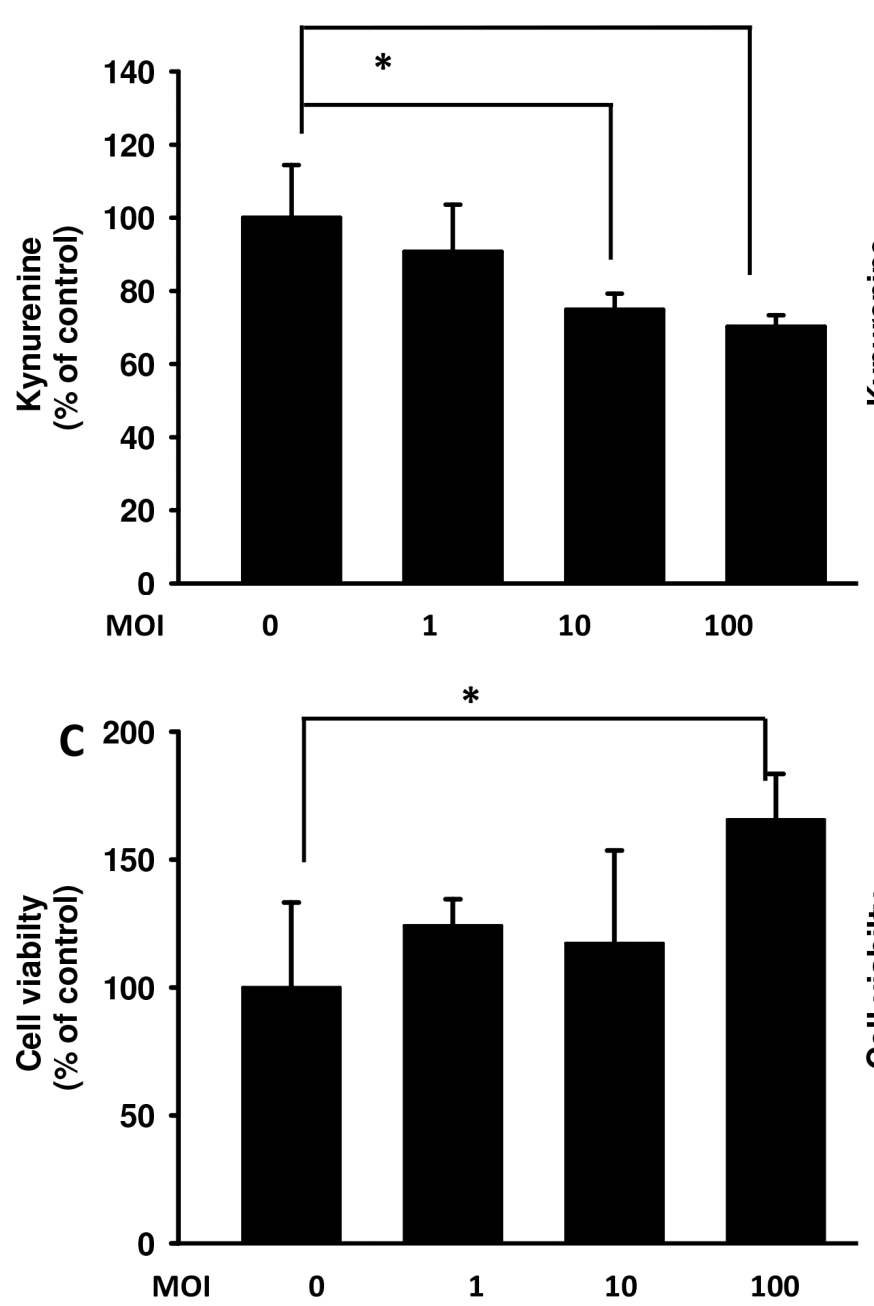

\section{Salmonella regulated IDO expression in vivo and inhibits tumor growth}

Tumor cells can create an immune escape microenvironment to facilitate their growth by releasing IDO themselves. Thus, analyzing the IDO expression within a tumor region seems necessary. To verify our findings in vivo, tumor-bearing mice were inoculated with Salmonella $10^{6}$ colony-forming units (cfu) and sacrificed after 2 days. Tumor tissues were collected and analyzed by immunoblotting assay. The results showed that as the Salmonella treatment concentration increased, the expression of IDO decreased (Figure 5A) as previously described. The mean IDO expression for mice in the Salmonella treatment group decreased by $54-78 \%$ compared with those in the PBS-treated group. Salmonella was able to decrease the production of IDO both in vitro and in vivo. Furthermore, the antitumor effects of
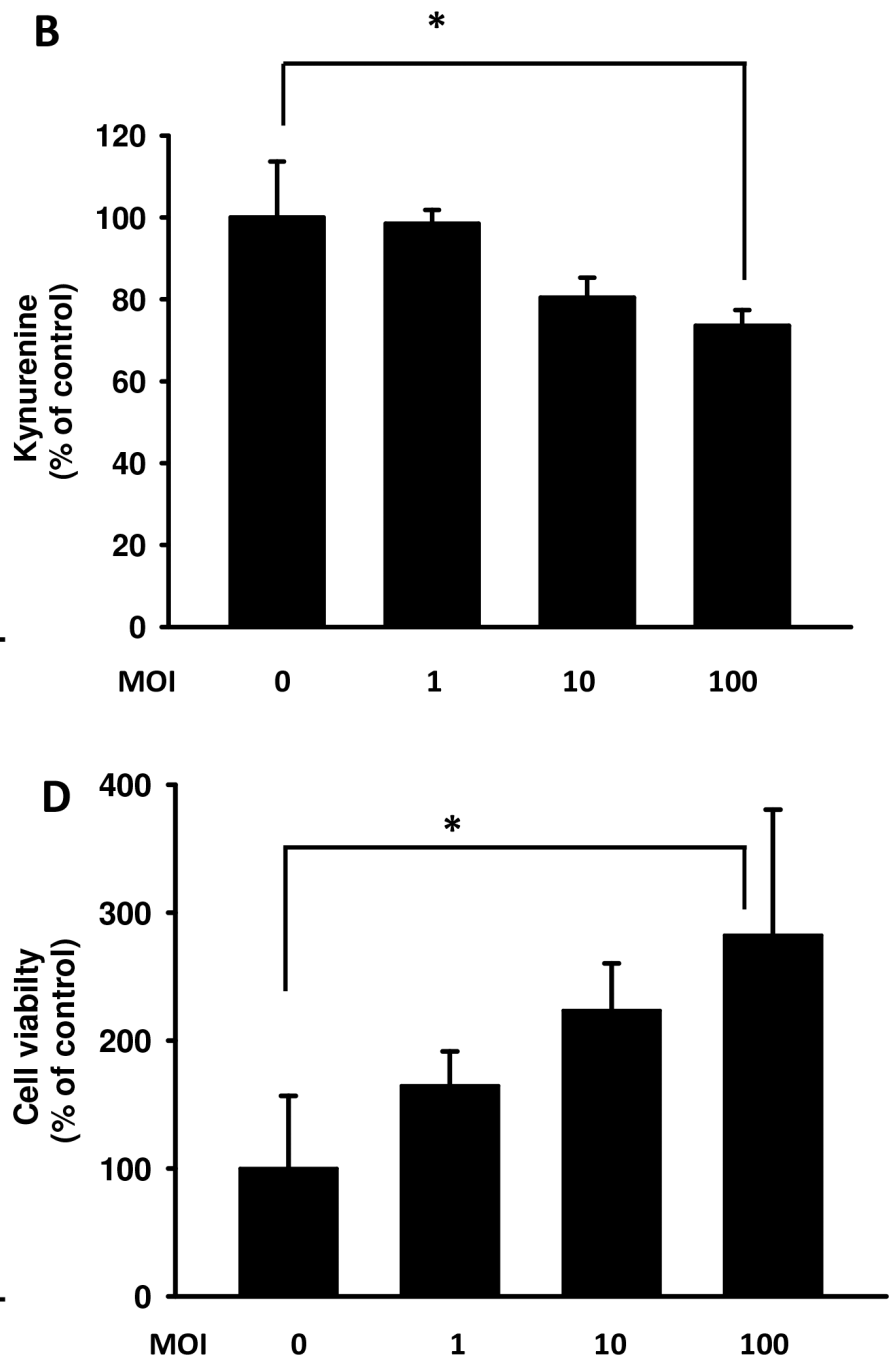

Figure 1: Salmonella (S.C.) regulated kynurenine and its impact on T cell survival. The B16F10 (A) and 4T1 (B) cells (105 cells/ well) were placed into 6-well plates. After treatment with various MOI of Salmonella for 90 min, cells were lysed and Western blot for autophagy marker and IDO were performed. The supernatants of B16F10 (C) or 4T1 (D) after treated with various multiplicity of infection (MOI) of Salmonella were added to Jurkat cells $\left(10^{6}\right)$ mixed with an equal amount of RPMI medium. After 3 days, cell were harvested and stained with trypan blue. $\left(n=3\right.$, data are mean \pm SD. $\left.{ }^{*} p<0.05\right)$. 
Salmonella were evaluated in terms of tumor growth of the mice bearing B16F10 or 4T1 tumors. As shown in Figure 5C and 5D, tumor growth was significantly decreased in mice treated with Salmonella compared to PBS-treated control mice. The average tumor volume in mice treated with Salmonella was lowered by $36 \%$ (B16F10) and 68\% (4T1) compared with mice treated with PBS. To further examine whether Salmonella targeted the tumor sites in mice bearing tumor, we injected Salmonella into tumor bearing mice, and observed the bacterial distribution within tumors. As shown in Figure 6A, Salmonella predominantly resided in the tumor. The number of apoptotic cells in the Salmonella-treated group was significantly higher than in the PBS-treated group (Figure 6B). Taken together, these results reveal

A

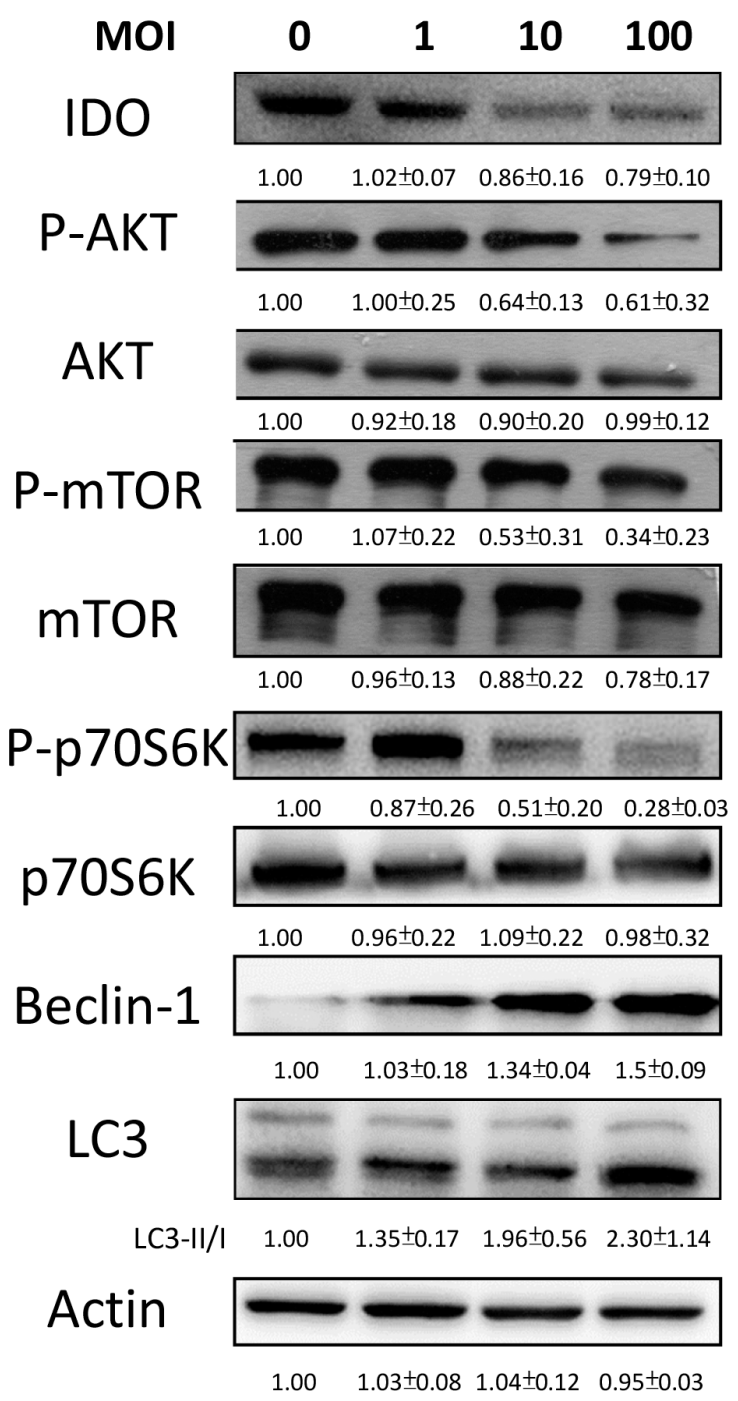

that systemic administration of Salmonella was capable of inhibiting tumor growth and increasing the tumor cell death.

\section{Effective $T$ cells infiltration increased due to administration of Salmonella}

The IDO-mediated tryptophan metabolic product kynurenine has a huge impact on $\mathrm{T}$ cells, leading to their inactivation, the inhibition of differentiation to effective cells and even apoptosis. Figure 1C and 1D indicate that Salmonella increased the likelihood of $\mathrm{T}$ cell survival through downregulating kynurenine production in vitro. The ability of IDO to induce T cell apoptosis has been shown. Previous studies have also

B

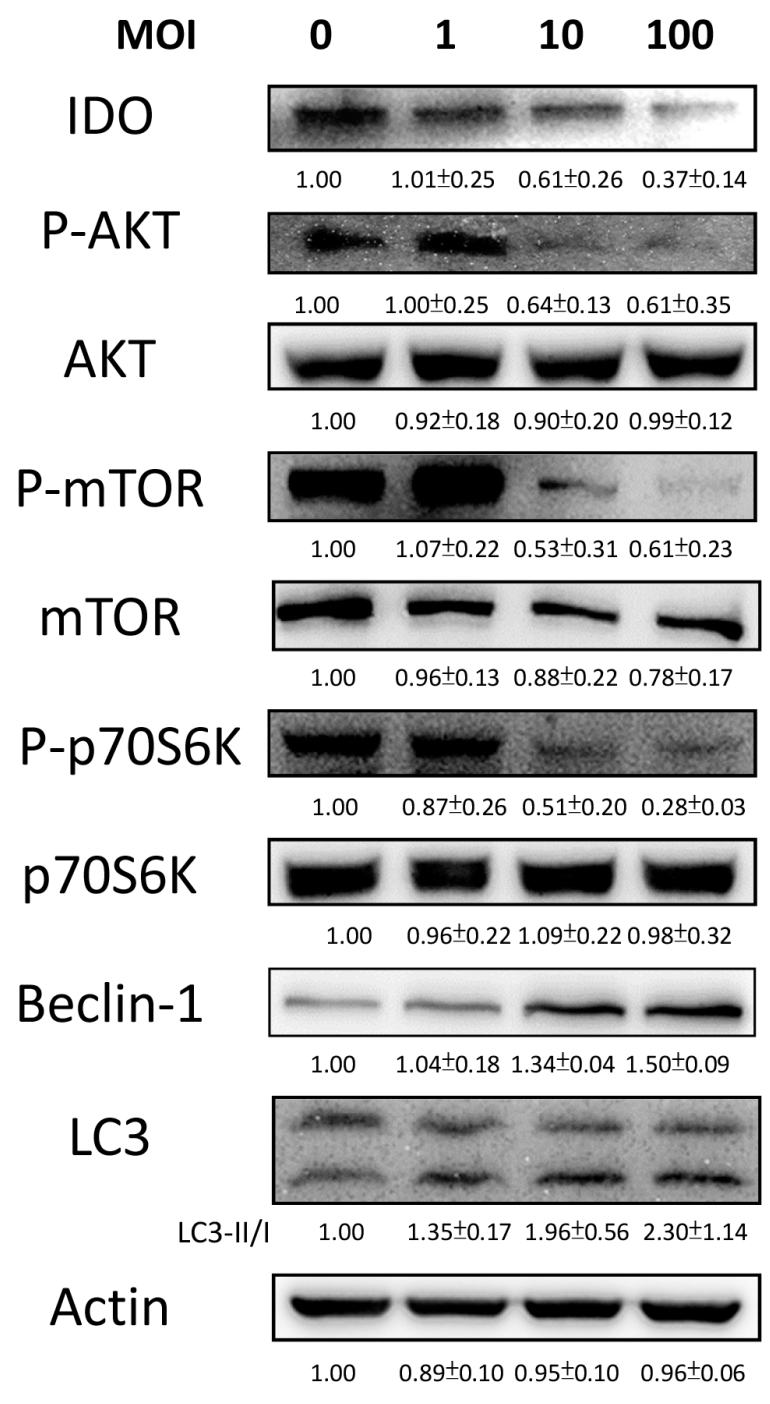

Figure 2: Salmonella (S.C.) regulated IDO through the inhibition of an autophagy signaling pathway. The B16F10 (A) and 4T1 (B) cells were placed into 6-well or 12-well plates and then infected with various multiplicity of infection (MOI) of Salmonella for 90 min. After 24 hours, cells were lysed and Western blot for IDO, AKT/mTOR/p70S6K and autophagy marker was performed. The inserted values indicate relative protein expression compared to $\beta$-actin. This experiment was repeated with similar results. 
A

B

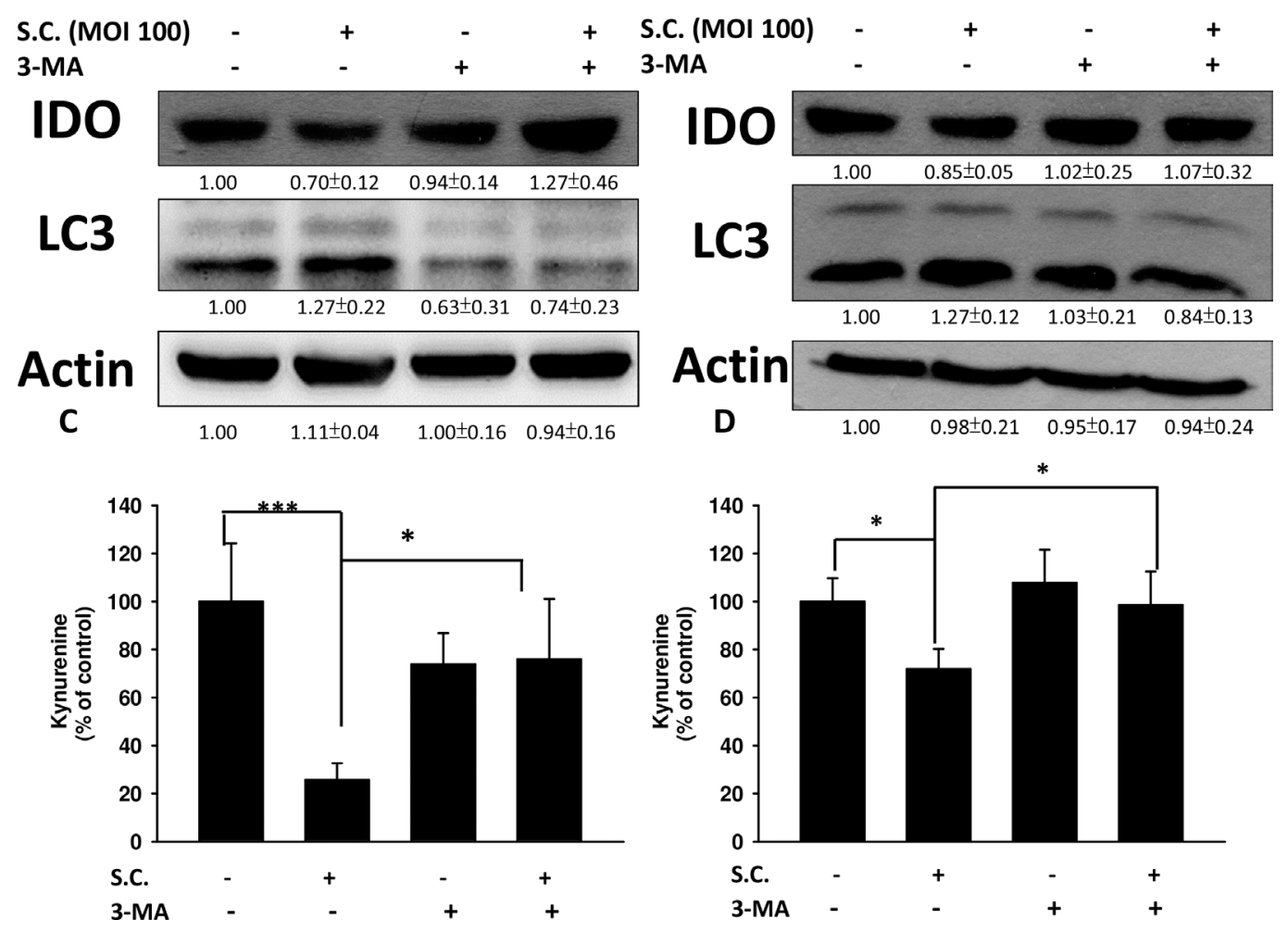

Figure 3: Autophagy inhibitor (3-MA) inhibited the Salmonella (S.C.)-induced decrease of IDO. The B16F10 (10 $)$ (A) and 4T1 $\left(10^{5}\right)$ (B) cells were pre-incubated with 3-MA $(2.5 \mathrm{mM})$ for $4 \mathrm{~h}$ prior to infection with Salmonella (multiplicity of infection (MOI) $\left.=100,10^{7} \mathrm{CFU} / 100 \mu \mathrm{L}\right)$ for $90 \mathrm{~min}$. The expression of IDO and LC3 protein (A and B) or percentage of control of kynurenine $(\mathbf{C}$ and $\mathbf{D})$ was performed. The inserted values indicate relative protein expression compared to $\beta$-actin. This experiment was repeated with similar results. $\left(n=3\right.$, mean \pm SD. $\left.{ }^{*} p<0.05 ; * * p<0.001\right)$.

A
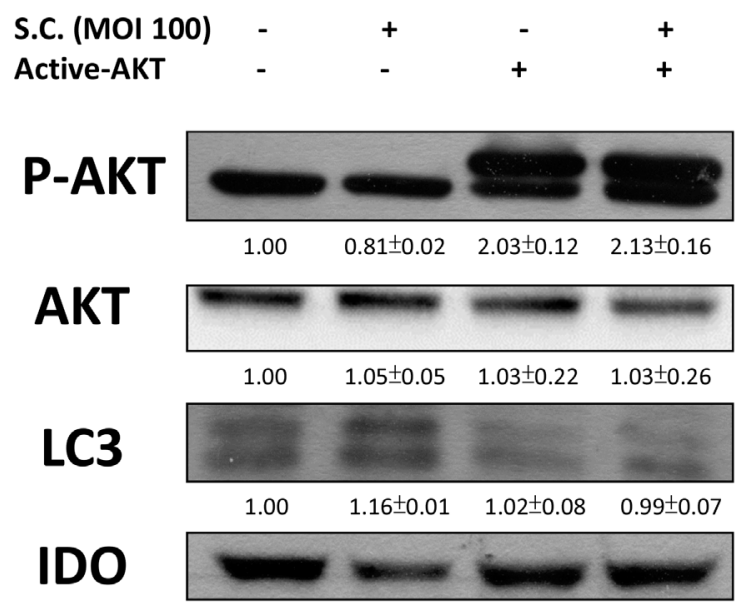

Actin
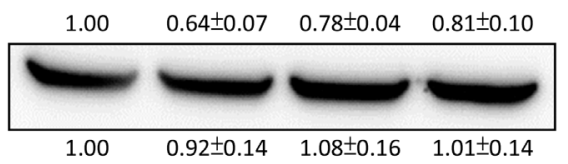

B

$\begin{array}{lllll}\text { S.C. (MOI 100) } & - & + & - & + \\ \text { Active-AKT } & - & - & + & +\end{array}$

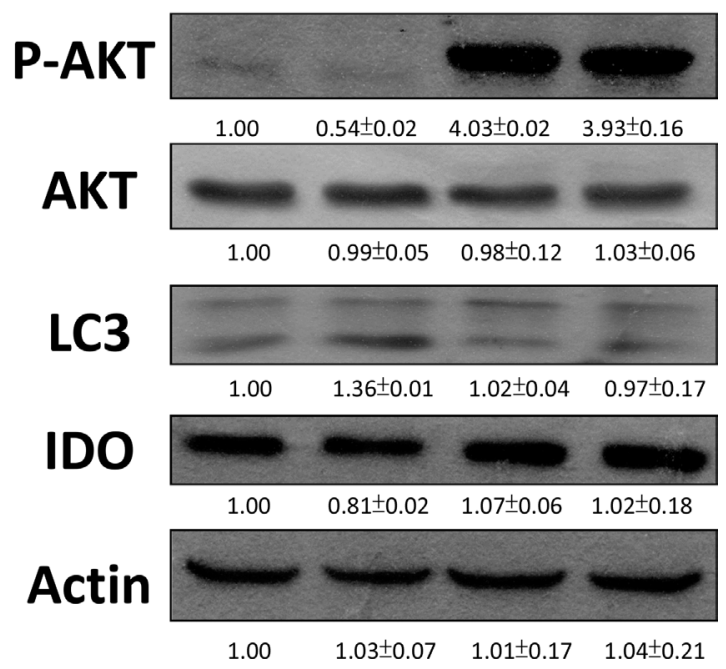

Figure 4: Constitutively active-AKT reduced Salmonella (S.C.)-induced decrease of IDO. The B16F10 $\left(10^{5}\right)$ and $4 \mathrm{~T} 1\left(10^{5}\right)$ cells were transfected with constitutively active AKT plasmid ( $5 \mu \mathrm{g}$ ) for 16 hours prior to infected with Salmonella (multiplicity of infection $\left.(\mathrm{MOI})=100,10^{7} \mathrm{CFU} / 100 \mu \mathrm{L}\right)$ for $90 \mathrm{~min}$. The expression of IDO, PAKT, AKT and LC3 protein in B16F10 (A) and 4T1 cells (B) was determined. The inserted values indicate relative protein expression compared to $\beta$-actin. This experiment was repeated with similar results. 
suggested that Salmonella increases the infiltration of immune cells and decreases the amount of IDO, leading to $\mathrm{T}$ cell survival both in vitro and in vivo. Hence, the relation between IDO and the infiltration of $\mathrm{CD}^{+} \mathrm{T}$ cells and $\mathrm{CD}^{+} \mathrm{T}$ cells was analyzed. The infiltration of $\mathrm{CD}^{+} \mathrm{T}$ cells and $\mathrm{CD}^{+} \mathrm{T}$ cells within the tumor region from $\mathrm{B} 16 \mathrm{~F} 10$ and $4 \mathrm{~T} 1$ tumorbearing mice were analyzed by immunofluorescence staining after treatment with PBS or Salmonella. The results of immunofluorescence staining are shown in Figure 7A. A notable increase of $\mathrm{CD}^{+} \mathrm{T}$-cell infiltrates in the tumors was observed in Salmonella-treated mice (Figure 7B). As shown in Figure 7B, the $\mathrm{CD}^{+} \mathrm{T}$ cell amount was not significantly higher in Salmonellatreated mice than in PBS-treated mice in both strains of mice. Taken together, these results indicate that Salmonella increased infiltrating immune cells and cell death in the tumors.

\section{DISCUSSION}

Immune tolerance has been a hall mark of cancer and one of major barriers developing efficient anticancer treatments. To overcome this hindrance, an effective strategy to evoke host immunity against tumor cells is necessary. Bacteria have a proven ability to inhibit tumor growth; however, the detailed mechanism for this still requires further investigation. Previous studies have suggested that as a pathogen, Salmonella not only summons host immune surveillance but can also quickly accumulate within the tumor region, even leading to tumor cell death [7]. Because of its strong properties of activating immunity and killing cancer cells, we believe that Salmonella are worth studying and applying to anticancer treatments. The safety concerns for using bacteria can be easily solved thanks to gene modification or antibodies $[28,29]$. However, this strain might exhibit
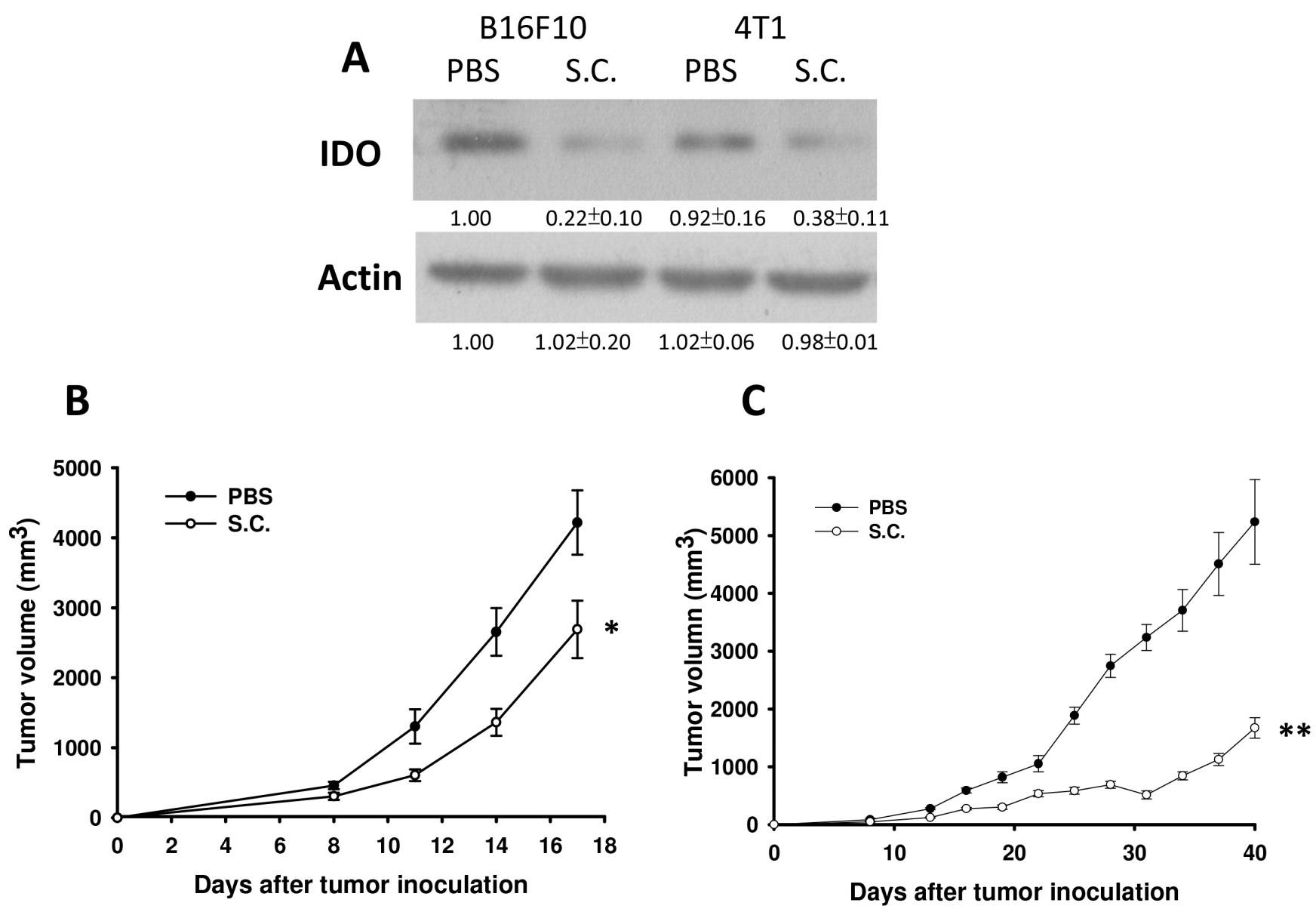

Figure 5: Salmonella (S.C.) inhibited tumor growth and downregulated IDO expression in vivo. Groups of C57BL/6 and BALB/c mice that had been inoculated subcutaneously with B16F10 $\left(10^{6}\right)$ and 4T1 $\left(10^{6}\right)$ at day 0 were treated i.p. with Salmonella $\left(10^{6}\right.$ CFU $/ 100 \mu \mathrm{L}$ ) at day 8 , respectively. Vehicle control mice were injected with PBS. (A) B16F10 and 4T1 tumor tissues were lysed and IDO Western blot analysis was performed on day 3. $(n=3$, mean $\pm \mathrm{SD})$ The inserted values indicate relative protein expression compared to $\beta$-actin. This experiment was repeated with similar results. The B16F10 (B) and 4T1 (C) tumor volumes were measured every 3 days after injection of Salmonella. The inserted values indicate relative protein expression compared to $\beta$-actin. This experiment was repeated with similar results. $\left(n=10\right.$, mean \pm SEM. $\left.{ }^{*} p<0.05 ; * *<0.01\right)$. 
lower ability of targeting and killing tumor cells when applied to clinical trial [30]. Researchers constructed an amino acid auxotrophic strain of Salmonella and found increased targeting and killing capacity with less toxicity and distribution comparing to original strain [31-40]. Moreover, the auxotrophic strain can be
A
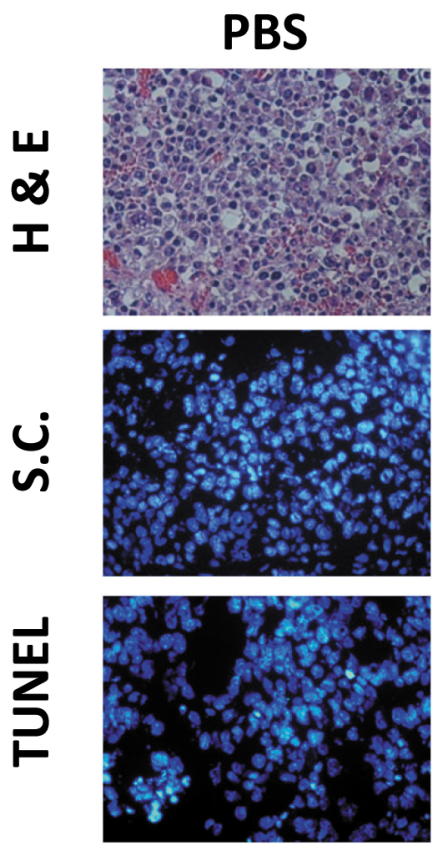

S.C.
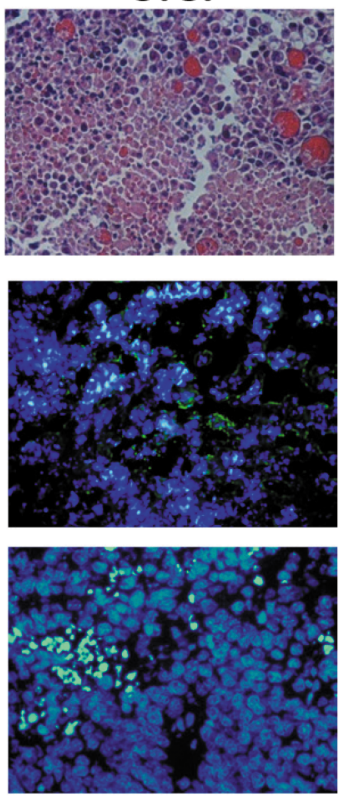

\section{T1}
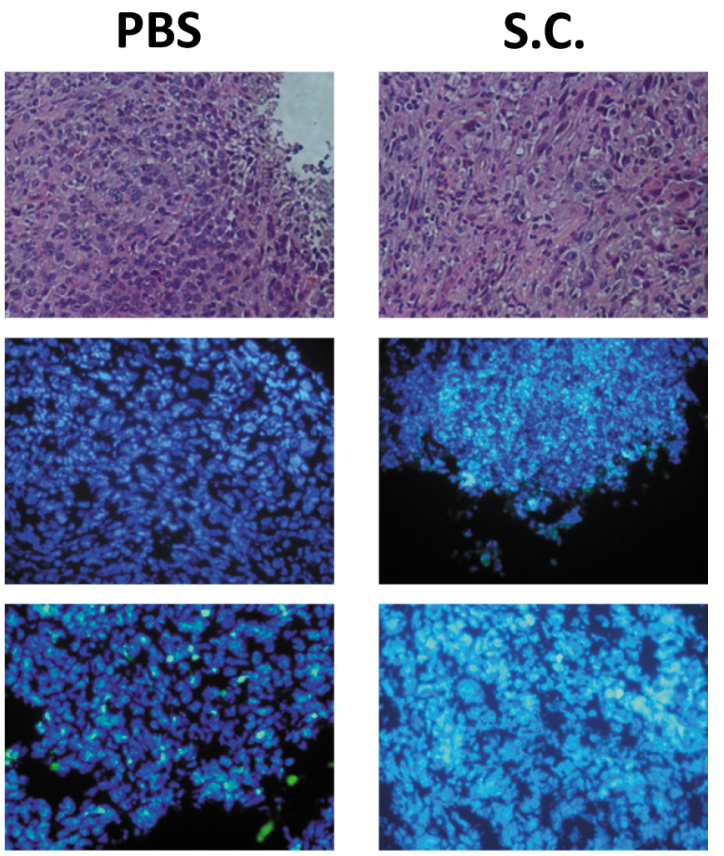
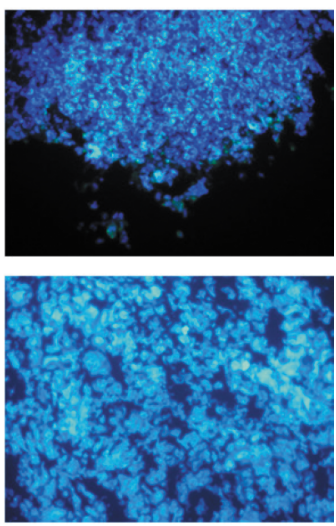

B

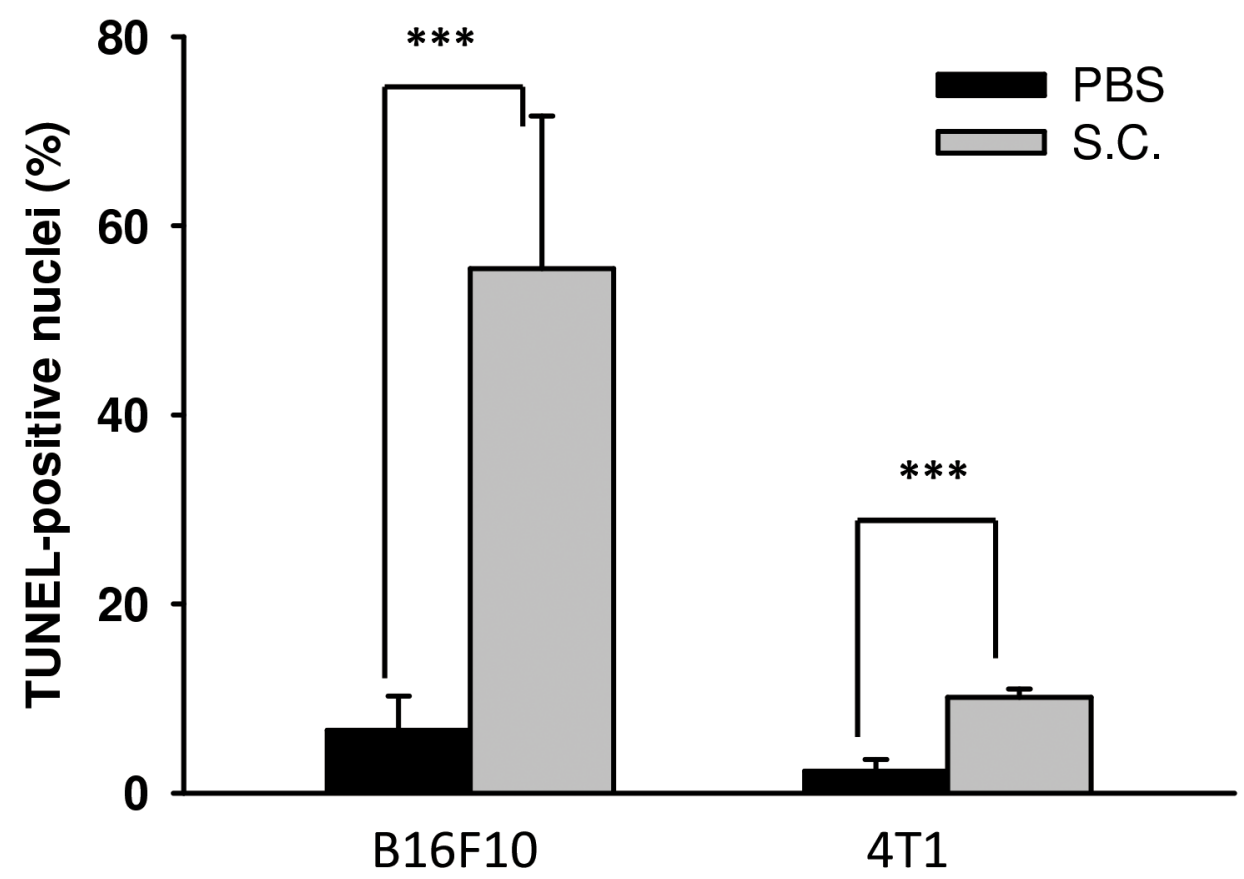

Figure 6: The accumulation of Salmonella (S.C.) within tumor region. Groups of C57BL/6 and BALB/c mice that had been inoculated subcutaneously with B16F10 $\left(10^{6}\right)$ and $4 \mathrm{~T} 1\left(10^{6}\right)$ at day 0 were injected i.p. with Salmonella $\left(10^{6} \mathrm{CFU} / 200 \mu \mathrm{L}\right)$ at day 8 , respectively. Vehicle control mice injected with PBS. (A) At day 10, tumors were removed for H\&E staining and immunohistochemistry staining with anti-Salmonella serum to visualize the Salmonella. Tumor cells undergo apoptosis in tumor-bearing mice treated with Salmonella (S.C.). The C57BL6 and BALB/c mice had been inoculated subcutaneously with B16F10 $\left(10^{6}\right)$ and 4 T1 (10 $)$ cells at day 0 were injected i.p. with Salmonella $\left(10^{6} \mathrm{CFU} / 100 \mu \mathrm{L}\right)$ at day 8. (A) Tumor tissues were removed at day 10 and TUNEL assay was used to analyze apoptotic cells. (B) TUNEL-positive cells were counted from three fields of high-density positive cells in each section to determine the percentage of apoptotic cells. (mean $\pm \mathrm{SD}, n=6$. $* * * p<0.001$ ). 
effectively utilized as a treatment targeting several types of cancer or metastatic region [43], and exhibit superior ability of reducing tumor volume comparing to standard chemotherapy $[44,45]$. These researches revealed a great promising way using genetically modified bacteria on cancer therapy.

Autophagy is a way in which cells maintain homeostasis and is considered an antitumor target [46], especially the AKT/mTOR pathway, one of the wellstudied and targeted autophagy signaling pathways [47]. As mentioned previously, our studies have demonstrated that Salmonella can cause autophagy of tumor cells, ultimately leading to tumor cell death $[22,25]$. Moreover, evidence shows that autophagy might participate in immune regulation [26]. Hence, we postulate that there are connections between Salmonella, autophagy and host immunity. We observed that the expression of phosphorylated AKT, mTOR and p70S6K decreased in Salmonella-infected tumor cells comparing to control groups (Figure 2A and 2B). The relation between autophagy and IDO was verified by using autophagy inhibitor and constitutively-AKT plasmid. The inhibitor and plasmid did not or slightly affect the expression of IDO and kynurenine, but reverse the decrease in IDO and kynurenine when cells were co-treated with Salmonella (Figures 3 and 4), which indicates that AKT/mTOR pathway might participate in Salmonella-mediated IDO expression. Interestingly, another study inferred that IDO can inhibit tryptophan-sufficiency signals triggering autophagy through the mTOR pathway [48]. Salmonella invasion results in the rapid induction of an acute state of cytosolic amino acid (AA) starvation, provoked by host membrane damage. Salmonella-induced AA starvation, in turn, down-regulates AKT/mTOR signaling while triggering autophagy and the integrated stress response pathway [49]. Salmonella altered mTOR activity, thereby impacting on host defense pathway. The AKT/ mTOR signaling pathways were found to be altered
A

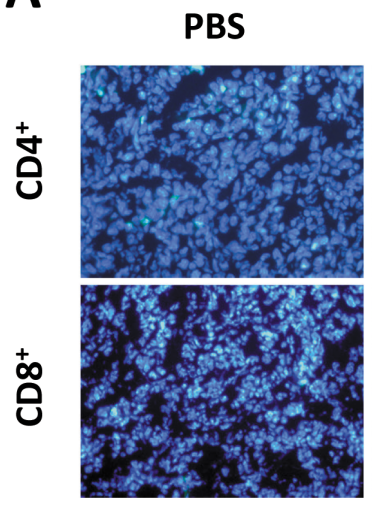

B

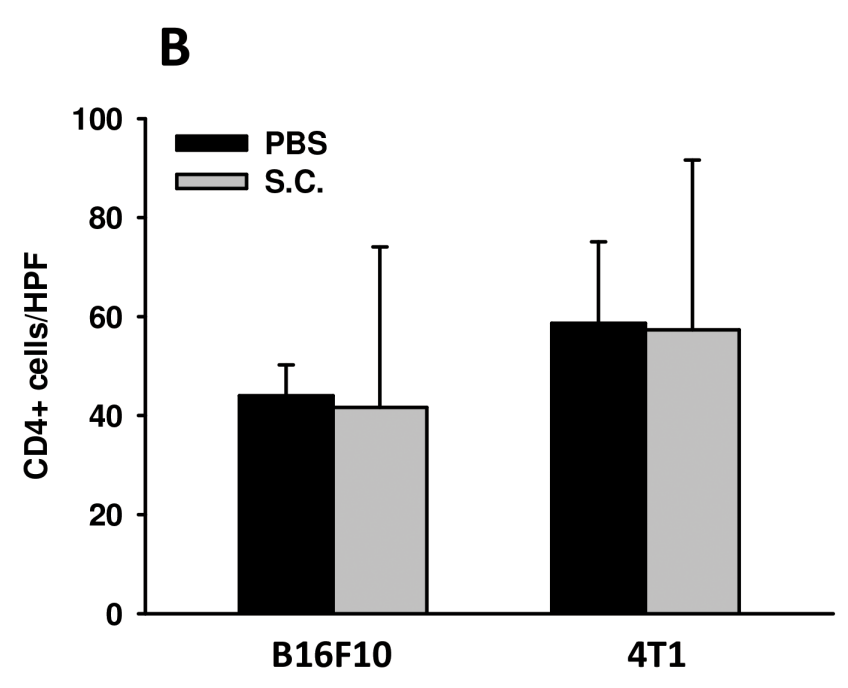

B16F10

S.C.
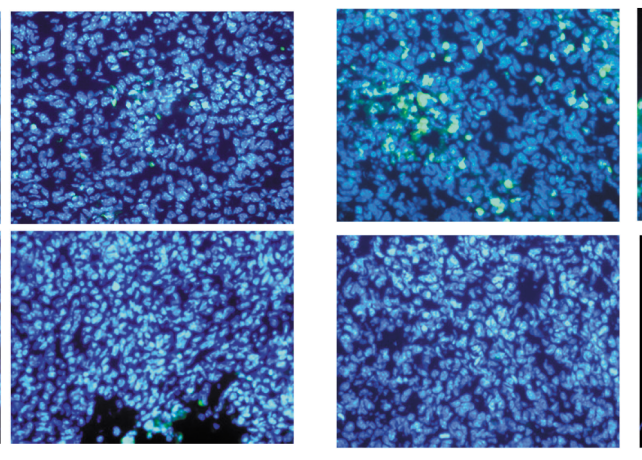

4T1

PBS
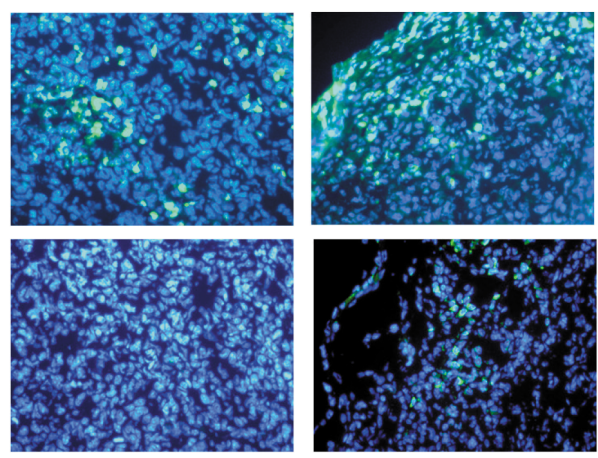

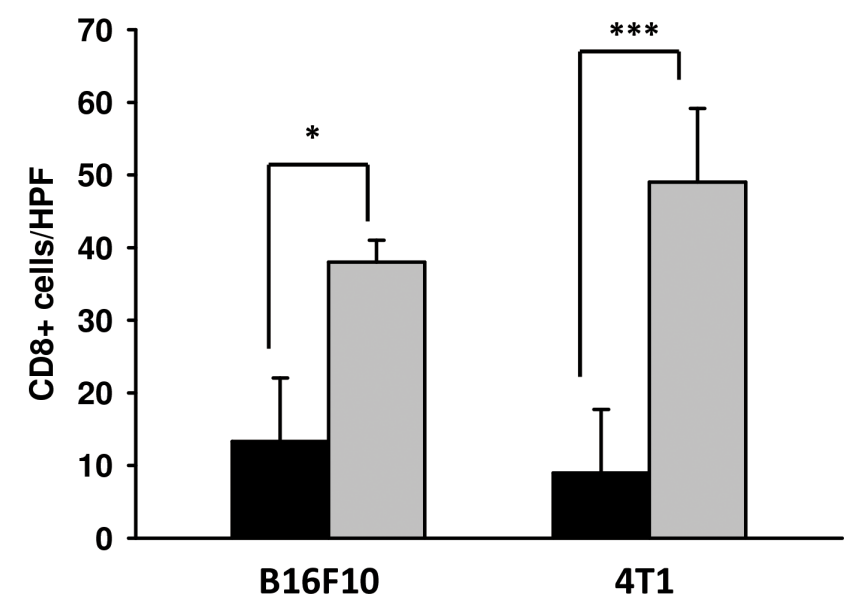

Figure 7: Increases in T-cell infiltrates in the tumors from tumor-bearing mice treated with Salmonella (S.C.). (A) The expression of $\mathrm{CD}^{+}$-and $\mathrm{CD}^{+}$positive cells in B16F10 and 4T1 tumor-bearing mice treated with Salmonella. The mice had been inoculated subcutaneously with B16F10 $\left(10^{6}\right)$ and 4T1 $\left(10^{6}\right)$ cells at day 0 and treated i.p. with Salmonella $\left(10^{6} \mathrm{CFU} / 100 \mu \mathrm{L}\right)$ at day 8 . Tumor tissues were excised after 2 days and immunofluorescence staining was performed with anti-CD4 and anti-CD8. (B) $\mathrm{CD} 4^{+}$and $(\mathbf{C}) \mathrm{CD} 8^{+} \mathrm{T}$ cells that infiltrated tumors were determined by averaging the cell numbers from three fields of the highest positively stained cell density at $\mathrm{x} 200$ magnification in each section. Each experiment was repeated three times with similar results. $\left(n=3\right.$, mean \pm SEM. $\left.{ }^{*} p<0.05 ; * * * p<0.001\right)$. 
during Salmonella infection [50]. Recently, we indeed demonstrated that Salmonella inhibit the expression of IDO in colorectal cancer [51]. There are some connection between AKT/mTOR pathway and IDO. The underlying and detail mechanism is worth studying.

We demonstrated that Salmonella can inhibit tumor growth in tumor-bearing mice (Figure 5C and 5D), and we investigated the possible mechanism causing the regression. Salmonella-induced decreases of IDO were seen both in vitro and in vivo. Figures $5 \mathrm{~A}$ and $5 \mathrm{~B}$ reveal that the expression of IDO within tumor regions can be downregulated by Salmonella. We verified these findings through analysis of CD4 and CD8 positive cells. Groups treated with Salmonella had a higher infiltration of CD8 positive cells compared to controls (Figure 7). This might be one of the explanations for why immune cells infiltrate the tumor region after treatment with Salmonella. Salmonella not only kills tumor cells by its bacterial toxicity but also recruits and even effectively activates host immune cells to attack; this might be a good topic of future study or might help in developing supporting treatments for patients who have impaired immunity. Salmonella-reduced IDO expression is not solely responsible for tumor immune tolerance. The tumor microenvironment contains immunosuppressive factors such as arginase, vascular endothelial growth factor and TGF- $\beta$. Recently, we also observed that Salmonella could inhibit the expression of programmed cell death protein 1 ligand 1 (PDL1) and programmed cell death protein 1 ligand 2 (PDL2) in melanoma cells. There are many other mechanisms by which the antitumor T cell response is inhibited. Herein, we provided one of possible mechanisms for Salmonella antitumor activity. Once successfully evoked and combined with other treatments, future Salmonellarelated treatments could shorten the treatment time and reduce side effects. The bacteria strain employed here has been utilized as a vector delivering DNA into mice [52]. Using Salmonella combined with drugs capable of reducing IDO and inhibiting tumor growth may be other choice for immunotherapy one day. In future studies, a further analysis of immune-related cytokines is needed, which might provide a reference for monitoring tumors or treatment progress after treatment with bacteria. In addition, because we demonstrated that Salmonella can break tumor immune tolerance, this might be another aspect to consider for antitumor treatments, even the application of bacteria to immunotherapy.

\section{MATERIALS AND METHODS}

\section{Bacteria, cell line, plasmid, reagents and mice}

Vaccine strain Salmonella enterica serovar choleraesuis (S. Choleraesuis; S.C.) (ATCC 15480) was obtained from Bioresources Collection and Research
Center (Hsinchu, Taiwan) [53]. Bacteria were maintained in L.B. plate and propagate in L.B. broth for using. B16F10 (mouse melanoma) [53] and 4T1 (mouse breast cancer) [54] cells were maintained in $10 \mathrm{~cm}$ Culture dish with Dulbecco's Modified Eagle Medium containing $1 \%$ Penicillin-Streptomycin (100 units $/ \mathrm{mL}$ penicillin and $100 \mu \mathrm{g} / \mathrm{mL}$ streptomycin), $2 \mathrm{mM} \mathrm{l-glutamine}$ and $10 \%$ fetal bovine serum. Jurkat cell line (human $\mathrm{T}$ lymphocyte; (ATCC TIB-152 ${ }^{\mathrm{TM}}$ )) was a kind gift from Professor Hui-Chen Chen (China Medical University) and maintained in HyClone RPMI 1640 medium containing $10 \%$ FBS. All cells were passaged every two to three days and incubated at $37^{\circ} \mathrm{C}, 5 \%$ $\mathrm{CO}_{2}$. Autophagy inhibitor (3-Methladenine; 3-MA) were purchased from Merk (Darmstadt, Germany). Constitutively active AKT plasmid was kindly provided by Dr. Chiau-Yuang Tsai (Department of molecular immunology, Osaka University) [55]. Cells were treated with inhibitors for $4 \mathrm{~h}$ or plasmids for 16 $\mathrm{h}$ in serum free medium prior to adding Salmonella $(\mathrm{MOI}=100)$ into cells for $90 \mathrm{~min}$ at $37^{\circ} \mathrm{C}, 5 \% \mathrm{CO}_{2}$. $\mathrm{C} 57 \mathrm{BL} / 6$ (B16F10) and BALB/c (4T1) mice were purchased from National Laboratory Animal Center of Taiwan. The animals were maintained in a pathogenfree animal care facility in isothermal conditions with regular photoperiods. The experimental protocol adhered to the rules of the Animal Protection Act of Taiwan and was approved by the Laboratory Animal Care and Use Committee of the China Medical University (permit number: 101-20-N).

\section{Western blot analysis}

The protein content in each sample was determined by bicinchoninic acid (BCA) protein assay (Pierce Biotechnology, Rockford, IL). Quantified each sample concentration to $60-80 \mu \mathrm{g}$ and add $4 \times$ SDS sample dye and then denatured sample for $10 \mathrm{~min}$ at $95^{\circ} \mathrm{C}$. Proteins were fractionated on SDS-PAGE, transferred onto Hybond enhanced chemiluminescence nitrocellulose membranes (Amersham, Little Chalfont, UK) and detected with antibodies against IDO (Thermo Scientific, Rockford, IL), the mammalian target of rapamycin (mTOR) (Cell Signaling, Danvers , MA), phosphormTOR (Cell Signaling), protein kinase B (AKT) (Santa Cruz Biotechnology, Inc. Santa Cruz, CA), phosphor-AKT (Santa Cruz Biotechnology, Inc.), p70S6K (Cell Signaling), phosphor-p70S6K (Cell Signaling), microtubule associated protein 1 light chain 3 (LC3) (Novus Biologicals, Littleton, $\mathrm{CO})$, Beclin (Novus) and $\beta$-actin (Sigma Aldrich). Rabbit anti-mouse IgG-peroxidase antibody (Sigma Aldrich) and goat anti-rabbit IgG-peroxidase antibody (Sigma Aldrich) were used as the secondary antibody and protein-antibody complexes were visualized by enhanced chemiluminescence system (Amersham) [56]. The signals were quantified with ImageJ software (rsbweb.nih.gov/ij) [57]. 


\section{IDO functional assay}

B16F10 or 4T1 cells were plated in 12 well culture plates for $24 \mathrm{~h}$, and treated with different MOI of Salmonella for $1.5 \mathrm{~h}$. After $24 \mathrm{~h}$, cells were collected and centrifuged at $12,000 \mathrm{rpm}$ at $4^{\circ} \mathrm{C}, 10 \mathrm{~min}$. The supernatants were then heated at $60^{\circ} \mathrm{C}, 15 \mathrm{~min} .100 \mu \mathrm{l}$ supernatants were added equal amount of IDO assay buffer $\left(\mathrm{K}_{2} \mathrm{HPO}_{4} 50 \mathrm{mM}\right.$ (Sigma Aldrich), ascorbic acid $20 \mathrm{mM}$ (Sigma Aldrich), methyl blue $10 \mu \mathrm{M}$ (Sigma Aldrich), catalase $100 \mu \mathrm{g} / \mathrm{ml}$ (Sigma Aldrich) and harvested at $37^{\circ} \mathrm{C}, 10 \mathrm{~min} .40 \mu \mathrm{l}$ of $30 \%$ TCA (Sigma Aldrich) were added and centrifuged at $3000 \mathrm{~g}, 15 \mathrm{~min}$. Afterward, the $125 \mu \mathrm{l}$ of supernatants were mixed in $125 \mu \mathrm{l}$ of $2 \%$ Erchlich's reagent (Sigma Aldrich) in acetic acid in 96well plates. The absorbances of kynurenine were detected by spectrophotometer at a wavelength of $\mathrm{A}_{490}$. The data were performed as percentage of control. All of the IDO functional assays were done in triplicate.

\section{Animal studies}

Groups of 10 C57BL/6 mice or BALB/c mice were inoculated with B16F10 or 4T1 $\left(10^{6}\right)$ cells, respectively. After 7-9 days when the tumors were about $50-100 \mathrm{~mm}^{3}$, Salmonella $\left(10^{6} \mathrm{cfu}\right)$ or PBS was injected intraperitoneally (i.p.) into mice bearing either B16F10 or 4T1 tumor. Tumor tissues were collected after 3 days and prepared for western blot. To analyze tumor volumes, tumors were measured every 3 days in two perpendicular axes using a tissue caliper and the tumor volumes were calculated as (length of tumor $) \times(\text { width of tumor })^{2} \times 0.45$. For immunoblotting assay, TUNEL assay and immunofluorescence staining, the tumor samples were collected on day 10 .

\section{TUNEL assay and immunofluorescence staining}

Cryostat sections $(5 \mathrm{~mm})$ were prepared and fixed. Tumor tissues were then processed in 5 - $\mu \mathrm{m}$ sections and stained with hematoxylin/eosin (H\&E). The accumulation of Salmonella within tumor region was described in the previous study [57]. Cell apoptosis within tumor region was analyzed by TUNEL assay according to the manufacturer's protocol (Promega, Madison, WI). TUNEL-positive cells were counted under the microscope in high-power field (HPF). The apoptosis index was determined by the percentage of TUNEL-positive among total cells of each sample [8]. To analyze the expression of CD4 or CD8 positive cells within tumor region, tumor cryostat sections were incubated with antibodies against CD4 (BD Biosciences, San Diego, CA) and CD8 (BD Biosciences). Slides were then incubated with fluorescein (FITC) anti-rat IgG $(\mathrm{H}+\mathrm{L})$ for secondary antibody and counter stained with 4',6-diamidino-2-phenylindole (DAPI). The infiltrating cells were quantified by averaging the number of each cell type in three areas of highest cell density at x400 magnification in each section [8].

\section{Cell viability assay}

Tumor cells were plated in 6 well culture plates and treated with various MOI of Salmonella for $1.5 \mathrm{~h}$ after cells have been seeded for $24 \mathrm{~h}$. The supernatants of Salmonellatreated B16F10 or 4T1 were added to Jurkat cells mixed with equal amount of RPMI medium. After 3 days, cell survival was assessed using the trypan blue exclusion assay [25]. All of the IDO apoptosis assays were done in triplicate.

\section{Statistical analysis}

The unpaired, two-tailed Student $t$ test was used to determine the differences between groups for comparisons of kynurenine, tumor volume, tumor weights, $\mathrm{T}$ cell death. The $p$ value less than 0.05 is regarded statistically significant.

\section{ACKNOWLEDGMENT}

This work was supported by grants from the Ministry of Science and Technology, Taiwan (MOST 104-2320-B-039-042-MY3).

\section{CONFLICTS OF INTEREST}

The authors declare no conflict of interest.

\section{REFERENCES}

1. Coley WB. Contribution to the Knowledge of Sarcoma. Ann Surg 1891; 14:199-220.

2. Nauts HC, Fowler GA, Bogatko FH. A review of the influence of bacterial infection and of bacterial products (Coley's toxins) on malignant tumors in man; a critical analysis of 30 inoperable cases treated by Coley's mixed toxins, in which diagnosis was confirmed by microscopic examination selected for special study. Acta Med Scand Suppl 1953; 276:1-103.

3. Brunschwig A. The efficacy of coley's toxin in the treatment of sacroma: an experimental study. Ann Surg 1939; 109:109-113.

4. Mose JR, Oese JR. Oncolysis by Clostridia. I. Activity of Clostridium Butyricum (M-55) and Other Nonpathogenic Clostridia against the Ehrlich Carcinoma. Cancer Res 1964; 24: 212-216.

5. Kawai K, Miyazaki J, Joraku A, Nishiyama H, Akaza H. Bacillus Calmette-Guerin (BCG) immunotherapy for bladder cancer: current understanding and perspectives on engineered BCG vaccine. Cancer Science. 2013; 104: 22-27.

6. Thornlow DN, Brackett EL, Gigas JM, Van Dessel N, Forbes NS. Persistent enhancement of bacterial motility increases tumor penetration. Biotechnol Bioeng 2015; 112: 2397-2405.

7. Forbes NS. Engineering the perfect (bacterial) cancer therapy. Nat Rev Cancer 2010; 10:785-794. 
8. Lee CH, Wu CL, Tai YS, Shiau AL. Systemic administration of attenuated Salmonella choleraesuis in combination with cisplatin for cancer therapy. Mol Ther 2005; 11:707-716.

9. Pawelek JM, Low KB, Bermudes D.J. Tumor-targeted Salmonella as a novel anticancer vector. Cancer Res 1997 57:4537-4544.

10. Lu B, Finn OJ. T-cell death and cancer immune tolerance. Cell Death Differ 2008; 15:70-79.

11. Mapara MY, Sykes M. Tolerance and cancer: mechanisms of tumor evasion and strategies for breaking tolerance. $\mathrm{J}$ Clin Oncol 2004; 22:1136-1151.

12. Hix LM, Karavitis J, Khan MW, Shi YH, Khazaie K, Zhang M. Tumor STAT1 transcription factor activity enhances breast tumor growth and immune suppression mediated by myeloid-derived suppressor cells. J Biol Chem 2013; 288:11676-11688

13. Dalotto-Moreno T, Croci DO, Cerliani JP, Martinez-Allo VC, Dergan-Dylon S, Mendez-Huergo SP, Stupirski JC, Mazal D, Osinaga E, Toscano MA, Sundblad V, Rabinovich GA, Salatino M. Targeting galectin-1 overcomes breast cancerassociated immunosuppression and prevents metastatic disease. Cancer Res 2013; 73:1107-1117.

14. Flavell RA, Sanjabi S, Wrzesinski SH, Licona-Limon P. The polarization of immune cells in the tumour environment by TGF- $\beta$. Nat Rev Immunol 2010; 10:554-567.

15. Fallarino F, Grohmann U, Puccetti P. Indoleamine 2,3-dioxygenase: from catalyst to signaling function. Eur J Immunol 2012; 42:1932-1937.

16. Brandacher G, Perathoner A, Ladurner R, Schneeberger S, Obrist P, Winkler C, Werner ER, Werner-Felmayer G, Weiss HG, Gobel G, Margreiter R, Konigsrainer A, Fuchs D, Amberger A. Prognostic value of indoleamine 2,3-dioxygenase expression in colorectal cancer: effect on tumor-infiltrating $\mathrm{T}$ cells. Clin Cancer Res 2006;12:1144-1151.

17. Muller AJ, DuHadaway JB, Donover PS, Sutanto-Ward E, Prendergast GC. Inhibition of indoleamine 2,3-dioxygenase, an immunoregulatory target of the cancer suppression gene Bin1, potentiates cancer chemotherapy. Nat Med 2005; 11: 312-319.

18. Munn DH. Indoleamine 2,3-dioxygenase, tumor-induced tolerance and counter-regulation. Curr Opin Immunol 2006; 18:220-225.

19. Hou DY, Muller AJ, Sharma MD, DuHadaway J, Banerjee T, Johnson M, Mellor AL, Prendergast GC, Munn DH. Inhibition of indoleamine 2,3-dioxygenase in dendritic cells by stereoisomers of 1-methyl-tryptophan correlates with antitumor responses. Cancer Res 2007; 67:792-801.

20. Lee $\mathrm{CH}$, Hsieh JL, Wu CL, Hsu PY, Shiau AL. T cell augments the antitumor activity of tumor-targeting Salmonella. Appl Microbiol Biotechnol 2011; 90:1381-1388.

21. Saccheri F, Pozzi C, Avogadri F, Barozzi S, Faretta M, Fusi P, Rescigno M. Bacteria-induced gap junctions in tumors favor antigen cross-presentation and antitumor immunity. Sci Transl Med 2010; 2:44ra57.
22. Chang WW, Lee CH. Salmonella as an innovative therapeutic antitumor agent. Int J Mol Sci 2014;15:14546-14554.

23. Klionsky DJ, Emr SD. Autophagy as a regulated pathway of cellular degradation. Science 2000; 290:1717-1721.

24. Pattingre S, Levine B. Bcl-2 inhibition of autophagy: a new route to cancer? Cancer Res 2006; 66:2885-2888.

25. Lee CH, Lin ST, Liu JJ, Chang WW, Hsieh JL, Wang WK. Salmonella induce autophagy in melanoma by the downregulation of AKT/mTOR pathway. Gene Ther 2014; 21:309-316.

26. Yan J, Wang ZY, Yang HZ, Liu HZ, Mi S, Lv XX, Fu XM, Yan HM, Zhang XW, Zhan QM, Hu ZW. Timing is critical for an effective anti-metastatic immunotherapy: the decisive role of IFN $\gamma / \mathrm{STAT} 1-$ mediated activation of autophagy. PloS one 2011; 6:e24705.

27. Fallarino F1 GU, Vacca C, Bianchi R, Orabona C, Spreca A, Fioretti MC, Puccetti P. T cell apoptosis by tryptophan catabolism. Cell Death Differ 2002; 9:1069-1077.

28. Low KB, Ittensohn M, Le T, Platt J, Sodi S, Amoss M, Ash O, Carmichael E, Chakraborty A, Fischer J, Lin SL, Luo X, Miller SI, Zheng L, King I, Pawelek JM, et al. Lipid A mutant Salmonella with suppressed virulence and TNF $\alpha$ induction retain tumor-targeting in vivo. Nat Biotechnol 1999; 17:37-41.

29. Lee $\mathrm{CH}$. Engineering bacteria toward tumor targeting for cancer treatment: current state and perspectives. Appl Microbiol Biotechnol 2012 ;93:517-523.

30. Toso JF, Gill VJ, Hwu P, Marincola FM, Restifo NP, Schwartzentruber DJ, Sherry RM, Topalian SL, Yang JC, Stock F, Freezer LJ, Morton KE, Seipp C, Haworth L, Mavroukakis S, White D, et al. Phase I study of the intravenous administration of attenuated Salmonella typhimurium to patients with metastatic melanoma. J Clin Oncol 2002; 20:142-152.

31. Zhao M, Yang M, Li XM, Jiang P, Baranov E, Li S, Xu M, Penman S, Hoffman RM. Tumor-targeting bacterial therapy with amino acid auxotrophs of GFP-expressing Salmonella typhimurium. Proc Natl Acad Sci U S A 2005; 102:755-760.

32. Matsumoto $\mathrm{Y}$, Miwa S, Zhang $\mathrm{Y}$, Zhao M, Yano S, Uehara F, Yamamoto M, Hiroshima Y, Toneri M, Bouvet M, Matsubara H, Tsuchiya H, Hoffman RM. Intraperitoneal administration of tumor-targeting Salmonella typhimurium A1-R inhibits disseminated human ovarian cancer and extends survival in nude mice. Oncotarget 2015; 6:11369-11377.

33. Hiroshima Y, Zhang Y, Zhao M, Zhang N, Murakami T, Maawy A, Mii S, Uehara F, Yamamoto M, Miwa S, Yano S, Momiyama M, Mori R, Matsuyama R, Chishima T, Tanaka K, Ichikawa Y, Bouvet M, Endo I, Hoffman RM. Tumor-Targeting Salmonella typhimurium A1-R in Combination with Trastuzumab Eradicates HER-2-Positive Cervical Cancer Cells in Patient-Derived Mouse Models. PLoS One 2015;10:e0120358.

34. Zhang Y, Miwa S, Zhang N, Hoffman RM, Zhao M. Tumortargeting Salmonella typhimurium A1-R arrests growth of breast-cancer brain metastasis. Oncotarget 2015; 6:2615-2622. 
35. Miwa S, Zhang Y, Baek KE, Uehara F, Yano S, Yamamoto M, Hiroshima Y, Matsumoto Y, Kimura H, Hayashi K, Yamamoto N, Bouvet M, Tsuchiya H, Hoffman RM, Zhao M. Inhibition of spontaneous and experimental lung metastasis of soft-tissue sarcoma by tumor-targeting Salmonella typhimurium A1-R. Oncotarget 2014; 5:12849-12861.

36. Hiroshima Y, Zhang Y, Murakami T, Maawy A, Miwa S, Yamamoto M, Yano S, Sato S, Momiyama M, Mori R, Matsuyama R, Chishima T, Tanaka K, Ichikawa Y, Bouvet M, Endo I, Zhao M, Hoffman RM. Efficacy of tumor-targeting Salmonella typhimurium A1-R in combination with anti-angiogenesis therapy on a pancreatic cancer patient-derived orthotopic xenograft (PDOX) and cell line mouse models. Oncotarget 2014; 5:12346-12357.

37. Yano S, Zhang Y, Zhao M, Hiroshima Y, Miwa S, Uehara F, Kishimoto H, Tazawa H, Bouvet M, Fujiwara T, Hoffman RM. Tumor-targeting Salmonella typhimurium A1-R decoys quiescent cancer cells to cycle as visualized by FUCCI imaging and become sensitive to chemotherapy. Cell Cycle 2014; 13:3958-3963.

38. Yam C, Zhao M, Hayashi K, Ma H, Kishimoto H, McElroy M, Bouvet M, Hoffman RM. Monotherapy with a tumor-targeting mutant of S. typhimurium inhibits liver metastasis in a mouse model of pancreatic cancer. J Surg Res 2010; 164:248-255.

39. Zhao M, Geller J, Ma H, Yang M, Penman S, Hoffman RM. Monotherapy with a tumor-targeting mutant of Salmonella typhimurium cures orthotopic metastatic mouse models of human prostate cancer. Proc Natl Acad Sci U S A 2007; 104:10170-10174.

40. Zhao M, Yang M, Ma H, Li X, Tan X, Li S, Yang Z, Hoffman RM. Targeted therapy with a Salmonella typhimurium leucine-arginine auxotroph cures orthotopic human breast tumors in nude mice.Cancer Res 2006; 66:7647-7652.

41. Hayashi K, Zhao M, Yamauchi K, Yamamoto N, Tsuchiya H, Tomita K, Hoffman RM. Cancer metastasis directly eradicated by targeted therapy with a modified Salmonella typhimurium. J Cell Biochem 2009; 106:992-998.

42. Kimura H, Zhang L, Zhao M, Hayashi K, Tsuchiya H, Tomita K, Bouvet M, Wessels J, Hoffman RM. Targeted therapy of spinal cord glioma with a genetically modified Salmonella typhimurium. Cell Prolif 2010; 43:41-48.

43. Miwa S YS, Zhang Y, Matsumoto Y, Uehara F, Yamamoto M, Hiroshima Y, Kimura H, Hayashi K, Yamamoto N, Bouvet M, Tsuchiya H, Hoffman RM, Zhao M. Tumor-targeting Salmonella typhimurium A1-R prevents experimental human breast cancer bone metastasis in nude mice. Oncotarget 2014; 5:7119-7125.

44. Hiroshima Y, Zhao M, Maawy A, Zhang Y, Katz MH, Fleming JB, Uehara F, Miwa S, Yano S, Momiyama M, Suetsugu A, Chishima T, Tanaka K, Bouvet M, Endo I, Hoffman RM. Efficacy of Salmonella typhimurium A1-R versus chemotherapy on a pancreatic cancer patient-derived orthotopic xenograft (PDOX). J Cell Biochem 2014; 115: 1254-1261.
45. Hiroshima Y, Zhao M, Zhang Y, Maawy A, Hassanein MK, Uehara F, Miwa S, Yano S, Momiyama M, Suetsugu A, Chishima T, Tanaka K, Bouvet M, Endo I, Hoffman RM. Comparison of efficacy of Salmonella typhimurium A1-R and chemotherapy on stem-like and non-stem human pancreatic cancer cells. Cell Cycle 2013; 12:2774-2780.

46. Cao J, Miao Q, Miao S, Bi L, Zhang S, Yang Q, Zhou X, Zhang M, Xie Y, Zhang J, Wang S. Tetramethylpyrazine (TMP) exerts antitumor effects by inducing apoptosis and autophagy in hepatocellular carcinoma. Int Immunopharmacol 2015; 26:212-220.

47. Pan ST, Qin Y, Zhou ZW, He ZX, Zhang X, Yang T, Yang YX, Wang D, Qiu JX, Zhou SF. Plumbagin induces G2/M arrest, apoptosis, and autophagy via p38 MAPKand PI3K/Akt/mTOR-mediated pathways in human tongue squamous cell carcinoma cells. Drug Des Devel Ther 2015; 9: 1601-1626.

48. Metz R, Rust S, Duhadaway JB, Mautino MR, Munn DH, Vahanian NN, Link CJ, Prendergast GC. IDO inhibits a tryptophan sufficiency signal that stimulates mTOR: A novel IDO effector pathway targeted by D-1-methyltryptophan. Oncoimmunology 2012; 1:1460-1468.

49. Tattoli I, Philpott DJ, Girardin SE. The bacterial and cellular determinants controlling the recruitment of mTOR to the Salmonella-containing vacuole. Biol Open 2012; 1:1215-1125.

50. Budak G, Eren Ozsoy O, Aydin Son Y, Can T, Tuncbag N. Reconstruction of the temporal signaling network in Salmonellainfected human cells. Front Microbiol 2015; 20:730.

51. Wang WK, Lu MF, Kuan YD, Lee CH. The treatment of mouse colorectal cancer by oral delivery tumor-targeting Salmonella. Am J Cancer Res 2015; 5:2222-2228.

52. Wang WK, Kuan YD, Kuo CY, Lee CH. Connexin 43 gene therapy delivered by polymer-modified Salmonella in murine tumor models. Polymers 2014; 6:1119-1128.

53. Chang WW, Lai CH, Chen MC, Liu CF, Kuan YD, Lin ST, Lee CH. Salmonella enhance chemosensitivity in tumor through connexin 43 upregulation.Int J Cancer 2013; 133: 1926-1935.

54. Chang WW, Kuan YD, Chen MC, Lin ST, Lee CH. Tracking of mouse breast cancer stem-like cells with Salmonella. Exp Biol Med 2012; 237:1189-1196.

55. Shiau AL, Shen YT, Hsieh JL, Wu CL, Lee CH. Scutellaria barbata inhibits angiogenesis through downregulation of HIF-1 $\alpha$ in lung tumor. Environ Toxicol 2014; 29:363-370.

56. Lee CH, Lee SD, Ou HC, Lai SC, Cheng YJ. Eicosapentaenoic acid protects against palmitic acid-induced endothelial dysfunction via activation of the AMPK/eNOS pathway. Int J Mol Sci. 2014; 15:10334-10349.

57. Chang WW, Liu JJ, Liu CF, Liu WS, Lim YP, Cheng YJ, Lee $\mathrm{CH}$. An extract of Rhodobacter sphaeroides reduces cisplatininduced nephrotoxicity in mice. Toxins 2013; 5:2353-2365.

58. Lee $\mathrm{CH}, \mathrm{Wu} \mathrm{CL}$, Shiau AL. Salmonella choleraesuis as an anticancer agent in a syngeneic model of orthotopic hepatocellular carcinoma. Int J Cancer. 2008;122:930-935. 